\title{
A Relationship between Stakeholder Management and Business Performance in the Czech Republic
}

\author{
Ondřej Částek \\ Masaryk University, Czech Republic \\ ondrej.castek@econ.muni.cz \\ Martin Cenek \\ Masaryk University, Czech Republic \\ 180682@mail.muni.cz
}

The quality of a relationship with stakeholders is often perceived as a way to a competitive advantage of a company. In other words, many authors have defended a hypothesis that the application of stakeholder management leads to a higher business performance. However, empirical verification of such a hypothesis is not trivial. In the first place, the operationalization of the stakeholder management, quality of the relationship towards stakeholders or the importance of stakeholders is a challenge by itself. This article therefore aims to review empirical research of the relationship between stakeholder management and performance of companies located in the Czech Republic. Unfortunately, the authors conclude that studies with factual results from the Czech Republic are almost none. Only two studies explicitly examine the relationship between stakeholder management and business performance. On top of that, both of these studies suffer from an inadequate research design.

Key Words: stakeholder management, stakeholder relationship, stakeholder importance, business performance, empirical research JEL Classification: L21, M21 https://doi.org/10.26493/1854-6935.15.187-207

\section{Introduction}

In short, the stakeholder approach is a way of viewing an organization as the point of conflict between the relationships and interests of the organization's stakeholders, with the assumption that the organization has to maximize the benefits for all of the stakeholders, and that maximizing the benefits for all of the stakeholders will also maximize the organization's performance (here we touch the normative and instrumental approach).

For example, Post, Preston, and Sachs (2002a, 3) argue that the stakeholder 'view' of an organization is a 'basis for analysing and managing the 
numerous and diverse relationships that arise within this setting.' Freeman's (1984) acknowledged definition of the stakeholder approach states that it is about groups and individuals who can affect an organization and about managers' actions taken in response to these groups and individuals.'

In any case, in the literature we can find many statements justifying the stakeholder approach. For example Preston and Donaldson (1999) claim that 'conscientious stakeholder management can enhance organizational wealth', Mitchell, Agle, and Wood $(1997,878)$ argue, in their seminal paper, that, among other, 'failure to identify dangerous stakeholders would result in missed opportunities for mitigating the dangers and in lower levels of preparedness, where no accommodation is possible.' and according to Turnbull (1997), co-operation between stakeholders in a company's informational and management structure is a strength and a competitive advantage.

This is why the application of the stakeholder approach is not inconsistent with long-term benefit for the owners, but rather leads to greater efficiency within the organization, which benefits all groups of stakeholders. In Turnbull's view, the explanation for this is that the more relationships a company has, the greater the number of information channels the company has at its disposal, and therefore the more feedback the company receives.

The article aims to examine current research on the relationship between stakeholder management and performance of companies in the Czech Republic. The open question is how the application of stakeholder management can be operationalized when examining the relationship of this application towards company performance. Therefore, the article is structured as follows: in the first place, the stakeholder approach is defined, in contrast to the shareholder approach. Subsequently, the two basic forms of the stakeholder approach are presented, based on Berman et al. (1999), and the operationalization of the stakeholder approach concept is completed with the function of stakeholder utility. Discussion about the static and dynamic effects opens up the review of empirical studies of the relationship with stakeholders on performance, which continues with other studies focusing on the specific forms of the application of the stakeholder approach and their impact on performance. The conclusion summarizes the findings on the state of research on Czech companies. Several parts of this article are based on Ondřej Částek's doctoral thesis (2010). 


\section{Operationalization of the Stakeholder Approach}

\section{STAKEHOLDER AND SHAREHOLDER APPROACH}

The shareholder approach stresses the responsibility that managers have towards the company's owners. This responsibility is placed above all others. When pursuing this approach, the objective of managers is therefore to maximize the company's profit in such a way as to maximize the benefits for the owners. The word shareholder (sometimes also stockholder) can refer to a person owning shares. However, the shareholder approach looks at company owners in general, irrespective of the form of ownership (Č́stek 2010).

The shareholder approach is sometimes placed in direct opposition to the stakeholder approach in the sense of maximizing the value for the owners versus maximizing the value for all stakeholders. Nevertheless, the shareholder approach can also be understood as a 'subset' or special interpretation of the stakeholder approach (Jones, Wicks, and Freeman 2002, 26).

\section{STAKEHOLDER APPROACH MODELS}

The application of the stakeholder approach is not necessarily unambiguous in practice. The two most common forms are the model of strategic stakeholder management and the model of intrinsic stakeholder commitment (Berman et al. 1999, 488). In the first of these, the character and scope of the managers' interest in individual stakeholders is determined solely by the potential of the specific interest (concrete action) to improve the company's financial performance. In the second model, there is the assumption that businesses feel a certain internal commitment towards their stakeholders, this commitment helps to shape their strategy and this is reflected in the financial performance of the company.

Berman et al. (1999, 491-2) further divide the first of these models into two forms: direct and moderated. In the direct effects model they assume that the strategy and relationships to stakeholders have a direct and separate effect on the firm's financial performance. In the moderated model, they assume that the direct relationship between corporate strategy and the firm's financial performance is affected by the relationships with stakeholders.

A model of intrinsic stakeholder commitment is given below. Here it is assumed that the relationships with stakeholders are reflected in the corporate strategy, which is then reflected in financial performance. 


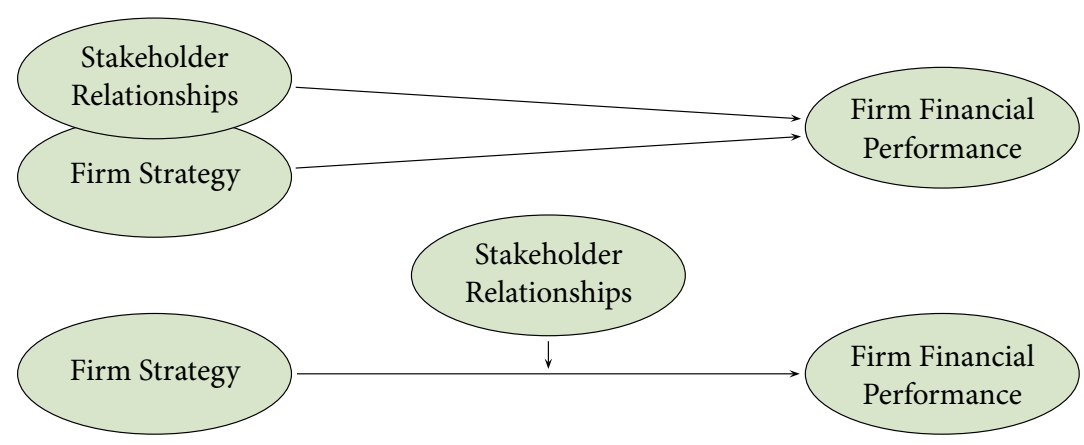

FIGURE 1 Models of Strategic Stakeholder Management (adapted from Berman et al. 1999, 493)

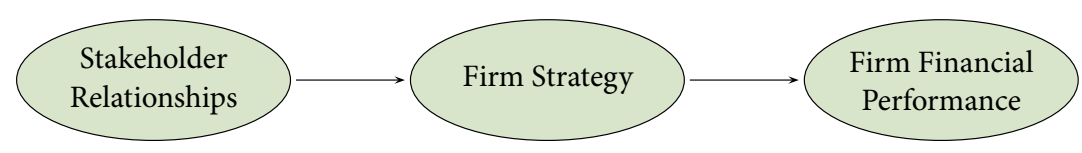

FIGURE 2 Model of Intrinsic Stakeholder Commitment (adapted from Berman et al. 1999, 494)

Berman et al. $(1999,502)$ tested the validity of these models using empirical data. Both models of strategic stakeholder management were verified, but the model of intrinsic stakeholder commitment was not. In the sample that was studied, the relationships with the stakeholders did not influence strategy.

\section{STAKEHOLDER UTILITY}

In their article, Harrison and Wicks (2013, 97-124) examine the value that a company represents for its stakeholders. They break down this value in terms of four perspectives and design - at least for selected generic groups of stakeholders - specific metrics, which managers or researchers may use to measure the fulfilment of stakeholders' expectations. However, these metrics can also be used to express the level and specific mode of stakeholder management in a particular company, and consequently to examine the correlation between stakeholder management and company performance.

Based on their study, Harrison and Wicks (2013) admit that searching for the function of stakeholder utility is a complex and complicated problem, which relates to more than just a value that can be described economically. Companies that provide their stakeholders with 
more utilities are better able to maintain their participation and support.

The view by Harrison and Wicks (2013) focuses on four factors that are extracted from the focus on stakeholders and values that are searched for from a relationship with the company. They are not only financial or tangible quantities, but they also include the consideration of the process and distribution of this value in accordance with the approach by Harrison, Bosse, and Phillips (2010, 58-74). The factors are defined in terms of the perceived utility for stakeholders from their relationship with the company, which is in line with the idea by Barney (2011) that the perception of a utility affects the utility itself. Thus, the resulting factors by Harrison and Wicks (2013, 97-124) take the following forms:

- Stakeholder utility connected with products and services.

- Stakeholder utility connected with organizational justice.

- Stakeholder utility arising from their affiliation to the company.

- Stakeholder utility connected with perceived opportunity costs.

This naturally does not negate the importance of financial metrics, which are in Barney's opinion (2011) incomplete themselves and bring the threat of oversimplifying the utility received by stakeholders who are variously involved in the success of the company. Efforts to create approaches providing guidance on understanding the creation of values from the perspective of stakeholders are certainly essential to ensure the success of companies and their own viability in the future.

Should subcategories of the utility be concretized, then Harrison, Bosse, and Phillips (2010, 57-74) defined the individual performance measures in terms of stakeholder utility from different perspectives of the parties involved. It is a set of non-financial metrics specific to given stakeholder groups with the expression of a specific utility. In addition to the definition of possible categories used to measure performance, potential proxies are designed for each of them too.

The question is, though, what is actually measured. Instead of using standard performance measures in financial terms, the entity 'happiness/ well-being' is used. Although the financial benefit may promote achieving the state of well-being, it does not represent the main goal of a stakeholder. Individual categories are thus relatively wide.

In terms of employees it is not only financial measures (e.g. wage, the value of benefits) that are applied, but also aspects of fairness in decisionmaking, respect for employees, the nature of career policy, company attitudes towards social issues, environmental friendliness, or consistent ac- 
TABLE 1 Examples of Performance Measures from Multiple Stakeholder Perspectives

\begin{tabular}{|c|c|c|}
\hline Category & $\begin{array}{l}\text { Potential categories for measuring } \\
\text { happiness/well-being }\end{array}$ & Potential proxies for researchers \\
\hline Employees & $\begin{array}{l}\text { Various components of employment } \\
\text { contract (i.e., pay, benefits, } \\
\text { perquisites). } \\
\text { Perceived fairness of decision making } \\
\text { processes. } \\
\text { Perceived treatment (i.e., respect, } \\
\text { inclusiveness). } \\
\text { Perceived authenticity (i.e., what firm } \\
\text { says, it does). } \\
\text { Consistency between stated vs. } \\
\text { realized firm values (i.e., honesty). } \\
\text { Promotion policies/upward mobility. } \\
\text { Firm's environmental performance. } \\
\text { Firm's position/performance on other } \\
\text { societal issues. } \\
\text { Also, objective measures such as } \\
\text { turnover, legal actions. }\end{array}$ & $\begin{array}{l}\text { Compensation and benefits. } \\
\text { Workplace benefits (i.e., fitness } \\
\text { centre, child care). } \\
\text { Legal actions or, if unionized, } \\
\text { grievances. } \\
\text { Productivity measures. } \\
\text { Inclusion on list of best } \\
\text { companies to work for. } \\
\text { Internal promotions to top } \\
\text { management. } \\
\text { Turnover. } \\
\text { KLD Health and Safety Concern } \\
\text { or Strength. } \\
\text { KLD Workforce Reductions. } \\
\text { KLD Pension/Benefits Concern } \\
\text { or Strength. } \\
\text { KLD Cash Profit Sharing. }\end{array}$ \\
\hline Customers & $\begin{array}{l}\text { Product/service features. } \\
\text { Perceived treatment during } \\
\text { transactions (i.e., respect, fairness). } \\
\text { Perceived authenticity (i.e., what firm } \\
\text { says, it does). } \\
\text { Firm's environmental performance. } \\
\text { Firm's position/performance on other } \\
\text { societal issues. } \\
\text { Also, objective measures such as repeat } \\
\text { business, legal actions. }\end{array}$ & $\begin{array}{l}\text { Growth in sales. } \\
\text { Consumer reports on } \\
\text { products/services. } \\
\text { Reputation rankings. } \\
\text { KLD Product Safety concern. } \\
\text { KLD Marketing or Contracting } \\
\text { Controversy. } \\
\text { KLD Quality Ranking of } \\
\text { Products. } \\
\text { KLD R\&D/Innovation Ranking. }\end{array}$ \\
\hline Suppliers & $\begin{array}{l}\text { Perceived treatment during } \\
\text { transactions (i.e., respect, fairness). } \\
\text { Firm's environmental performance. } \\
\text { Firm's position/performance on other } \\
\text { societal issues. } \\
\text { Nature of payments (i.e., size, speed). } \\
\text { Also, objective measures such as } \\
\text { longevity, availability of supplies. }\end{array}$ & $\begin{array}{l}\text { Days payable (from accounting } \\
\text { statements). } \\
\text { Longevity of supplier } \\
\text { relationships (available in 10-K } \\
\text { for some firms). } \\
\text { Legal actions. }\end{array}$ \\
\hline
\end{tabular}

NOTES Adapted from Harrison, Bosse, and Phillips (2010, 58-74).

tion in the context of values declared by a company as opposed to those that are actually applied.

These categories can be examined even indirectly, through the provided compensation and benefits, employment benefits, position of the 
company towards the labour unions, productivity measurement, position in the list of best employers, promotion system, and employee care. As for other stakeholder groups, potential categories for measuring happiness/well-being and potential proxies for researchers are established by analogy.

\section{Review of Empirical Studies}

PERFORMANCE AS THE MAIN MOTIVATION

FOR THE STAKEHOLDER APPROACH

Some authors comment on the issue of the relationship between stakeholder corporate management and performance from a somewhat different perspective as they automatically anticipate the outlined effect and they consider exerting influence on the financial performance of a company the major element of implementing the stakeholder approach.

The results of the study by Raise and Goedegebuure (2009, 62-75) show a strong motivation of management to using the stakeholder approach mainly due to effects on the financial performance and not because perceiving a certain commitment to stakeholders or because of their ethical standpoint. Thus, behaviour of managers determines the requirement to maximize profits. The survey was conducted on the research sample of 101 manufacturing companies in Indonesia, using a questionnaire as a tool for data collection.

Conclusions adopted by Raise and Goedegebuure (2009, 62-75) are also supported by the evidence from previously completed studies (Berman et al. 1999, 488-506; Post, Preston, and Sachs 2002a; 2002b). According to the Raise and Goedegebuure's study results, a constant contact with key stakeholders enables managers to gain a better position to assess the organizational objectives and to the subsequent use of mutually beneficial opportunities. In addition, the constant contact with key stakeholders allows averting potential conflicts before reaching a critical phase. Better information and proximity to stakeholders is thus used designedly for profit purposes.

\section{STATIC AND DYNAMIC IMPACT ON PERFORMANCE}

In the literature is often presented (and sometimes well-justified) general view that good relations with stakeholders have a positive effect on financial performance (Orlitzky, Schmidt, and Rynes 2003, 403-41; Roman, Hayibor, and Agle 1999, 109-25). 
Choi and Wang (2009, 895-907) examined the decomposition of the relationship between stakeholder management and financial performance on two levels, i.e. a dynamic basis (effects of the relationships on the growth in company performance) and a static one (effects of the relationships on maintaining company performance). Highly rated (wellbuilt) relationships with stakeholders help well-performing companies to maintain high profits; they also help companies with poor performance to recover faster from their unfavourable position. The study also underlines the important role of company relationships with key stakeholders in creating and maintaining the economic annuity. If the financially measured performance declines, the stakeholders provide the potential to remedy the situation.

Choi and Wang $(2009,895-907)$ confirmed the idea by analysing a series of first-order autoregression models. The obtained results indicated that the influence of good relationships with stakeholders on maintaining excellent financial performance is not as strong as the influence of other corporate resources (e.g. technological expertise), but it was defined as the only one that holds the promise to help the company revive its performance. The importance of positive relationships is thus more critical for performance recovery than it is for its actual maintaining.

THE RELATIONSHIP BETWEEN STAKEHOLDER MANAGEMENT AND A FIRM'S PERFORMANCE

Berman et al. (1999) set themselves the task of verifying the validity of the aforementioned models of strategic stakeholder management and intrinsic stakeholder commitment. They used a sample of companies from the top one hundred on the Fortune 500 list (for 1996), for which complete financial data for the years 1991-1996 was available. In total, they selected 81 companies from various industries. Financial performance as a dependent variable was measured using ROA (operating profit to total assets). The stakeholder approach as an independent variable was expressed through the companies' attitudes towards five defined 'stakeholder groups. These were relationships with employees, diversity, local communities, the natural environment and product quality and safety.

The KLD database tracks the companies from the Standard and Poor's 500 indexes and the Domini Social Index (150 companies). A large amount of data is available for these companies, for example on educational activities, recycling programmes, sponsorship, lawsuits, etc. (see below for more information). These individual items are then evaluated 
on a five-point Linkert scale, where -2 means negative activity and +2 positive activity. Berman et al. selected the data relating to the individual stakeholder groups chosen by them based on research into the literature. Here we will use the 'diversity' group as an example, providing some information about it at the same time (Berman et al. 1999, 505):

1. Areas of concern: the payment of fines as the result of controversial actions, no directors or senior management from traditionally under-represented groups.

2. Areas of strength: career advancement for women and people of different races, the participation of women, people of different races and/or mentally or physically disabled people on the board of directors, addressing employees' family problems related to their job, employing mentally or physically disabled people and progressive policies towards homosexual employees.

When using the traditional concept of generic stakeholder groups, the diversity group would fall within the communities group, as would the natural environment group. In terms of its content, the product quality and safety group corresponds with the group normally termed employees. More information about the composition of the other groups used by Berman et al. can be found in an appendix to their report (Berman et al. 1999, 505).

Berman et al. (1999) research confirmed the direct effect of the variables classified as employees and product quality and safety on the corporate financial performance. No such influence was observed for the other three variables, despite the fact that it had been suggested by previous research (Robinson and Dechant 1997; Waddock and Graves 1997). Berman et al. offer the explanation that the variables for communities and diversity, which are mainly important from a normative perspective, on their own do not have a direct effect on financial performance. The effect of the natural environment variable could have been limited by the fact that the companies under research were from many industries in which the importance of the environment and the way of protecting it might take different forms and have different impacts on financial performance. Another limiting factor could have been the location of the companies, which was not controlled for.

While a direct effect was only discovered for two variables, all five variables affected the relationship between strategy and financial performance in the Berman's et al. (1999) moderated model of strategic 
stakeholder management. This indicates that the dependency between relationships with stakeholders and financial performance is much more complex and cannot be reduced to the level of the dependency between relationship to one specific stakeholder and financial performance.

Unlike the models for strategic stakeholder management, the model for intrinsic stakeholder commitment was not verified by this research. Therefore, it was not the case that the companies' relationships with stakeholders influenced the creation of strategy for normative reasons, which is consistent with Rais and Goedegebuure (2009) result (see above). Here Berman et al. (1999) suggest including managers' values and motivations in the model in further research.

For our purposes, the important conclusion is that the dependence of financial performance on relationships with specific stakeholders was demonstrated, and more importantly, that this dependence cannot be fully explained when these relationships are isolated, but that it is necessary to examine them as being interrelated. It was also shown that the specific industry has an important effect.

\section{PRO-EMPLOYMENT ORIENTATION AND ITS IMPACT \\ ON PERFORMANCE}

De Bussy and Suprawan (2012) investigated in their paper two research questions, which should be of our interest: (RQ1) 'What is the impact of adopting employee orientation on corporate financial performance?' and (RQ2) 'How does the impact of employee orientation on corporate financial performance differ from that of orientation towards other primary stakeholder groups?' Based on more than 400 observations, they arrived to a conclusion that employee orientation matters, it matters a lot and its effect on corporate financial performance is stronger than the effect of orientation towards any other individual generic stakeholder group.

More importantly for us, de Bussy and Suprawan succeeded in operationalization of the stakeholder orientation using STA KOR - a scale measuring stakeholder orientation based on dialogue (de Bussy 2010). The rationalization of this decision follows. In the field of human resources practices, variables such as rewards, opportunities for promotion, participation, etc. are typically expected to explain employee satisfaction, motivation, retention and loyalty, which is further linked to overall firm performance, measured most often as profit, market share or customer satisfaction. However, the de Bussy and Suprawan's literature review led them to a strong opinion that none of these is synonymous with em- 
ployee orientation. Based on de Bussy (2010), they conclude that conceptualized stakeholder orientation is dialogue operationalized into dimensions of listening, positive regard and willingness to change. De Bussy and Suprawan then describe the employee orientation as an organization's inclination to engage in dialogic communication with its employees. The Bussy (2010) suggests, within the sTA KOR framework, operationalization of the dialogic communication with employees into five-item scale. One example of such item, measured with 7-point Likert scale, is 'Managers in this organization are prepared to listen to ideas from employees.' Also, de Bussy and Suprawan (2012) propose second conceptualization and operationalization, which can be complementary or substitutive to the concept of dialogue and which is employee-focused: employee concern, measured again with 7-point Likert scales on items such as 'Achieving work/life balance for employees is of central importance to our organization.'

\section{STUDIES CONDUCTED IN THE CZECH REPUBLIC}

The relationship between stakeholder management and company performance may differ throughout countries. Differences may result from several reasons: in the first place, it should be noted that the stakeholder approach was developed mainly in the us, i.e. in the conditions of the Anglo-Saxon way of company management. One of the reasons for the differences may be a different model of management bodies. The same effect can also have a different state of the economies, or the state of trading in stocks when the stock market price accurately reflects the economic development of only a handful of companies. Another source of differences will certainly represent legal systems and related practices in trade relations (Částek 2010).

The last factor is then represented by national and corporate cultures, manifesting themselves for example in the level of trust or cohesion at different levels. High trust means lower transaction costs in the economy and a better platform for improved relationships between economic entities, including stakeholders. Regarding cohesion, M. Bohatá (1998) states that 'National cultures exhibit both elements of cohesion and incohesion. On one side of the spectrum are African countries where loyalty to family and tribe makes cooperative economic behaviour of the capitalist model very difficult. On the other side of this spectrum we can point at Japan mentioned earlier and its collectivist ethos.'

For these reasons, the nature of the stakeholder approach in the Czech 
Republic may differ from the stakeholder approach in other countries. The optimal form of the stakeholder approach in relation to the corporate competitiveness in the Czech Republic may also be different. However, there are not many studies from the Czech environment. Although the stakeholder approach as such is used by many authors in their studies, e.g. Slabá, Starchon, and Jác (2014) use some procedures of stakeholder analysis to analyse marketing communication of universities, exploring the connections between stakeholder management and corporate performance is very rare. Below are presented studies that are closest to our research topic in more details.

Here, we briefly summarize papers that relate to the topic more freely. For example, Dohnalová (2007) as if turned the chosen perspective and examined what is important for the individual stakeholders in relation to the companies. However, in the end it is precisely the items identified by her what the companies must pay their attention to when managing relationships with stakeholders.

Šimberová and Pollard (2008) admit that 'selected aspects of stakeholder relationship management' can contribute 'to the enhancement of the value of the company's offer.' Nevertheless, it is not the goal of their work to test such a relationship. Petrovičová and Kašparová (2009) researched the attitudes of Czech and Slovak companies towards their stakeholders, again without examining the link to company performance. Based on thirteen case studies, Šmakalová (2012) identified 'key groups which the most influence the development and performance of the companies.' Furthermore, she suggested appropriate strategies for dealing with particular generic stakeholders. Dohnalová and Zimola (2015) concluded their paper with a claim that 'A Stakeholder Approach to business can be a factor which can significantly support the highest goals of a business.' Unfortunately, such a claim lacked support in the empirical part of their paper. We shall now have a closer look at several studies more related to our goal.

\section{Czech-Austrian Research AKTION}

A research entitled 'Comparative Analysis of Corporate Social Responsibility in Austria and Czech Republic' conducted between 2002 and 2003 focused on corporate social responsibility. The Czech team was represented by Milan Malý, Michal Theodor, and Jaromír Peklo (for only part of the project), all of whom work at the University of Economics in Prague. Among other things, the authors addressed the issues of cor- 
porate governance and the stakeholder model where they suggested indicators for measuring stakeholder satisfaction. They assumed that an organization could achieve its goals by satisfying its stakeholders' interests (Theodor 2004, 32). It is this measuring of satisfying stakeholders' interests that should testify about the success of an organization's management. The proposed indicators are presented in the book Řizeni a správa společností (Corporate Governance) (Malý et al. 2002, 82-9).

They verified their hypotheses on a sample of 40 companies; however, for most of them, they managed to get only about half of the necessary data (Theodor 2004, 35). The authors defined eight stakeholder groups for their research, which were expected to lead to sufficient coverage, and be operationalised for practical use. These groups included Owners, Senior Management, Other Employees, Creditors, Suppliers, Customers, State, and Society.

\section{Stakeholder Relationship Management in Industrial Markets in the Context of Current Marketing Concepts}

The objective of the research conducted by Šimberová $(2008,5)$ was 'to develop a methodology of coordination and interconnection of marketing and business activities using the tools of stakeholder relationship management, based on the processing of the latest theoretical and empirical knowledge.'

Šimberová (2008) concluded that relationships with stakeholders are managed separately in companies, while integrated stakeholder relationship management would bring synergies and higher value especially for customers and owners. Specifically, she states that 'creating and building long-term relationships and functioning networks of relationships with key stakeholders while respecting selected key principles of current marketing concepts is a potential for increasing the value of a complex market supply consisting of products and services.' However, she fails to prove these findings empirically; nevertheless, she at least examined the degree of stakeholder significance for market success $(N=160$, response rate $=$ $32 \%)$. The results are included in table 2; the range used is $1-$ minimal impact to 10 - crucial impact on the success of a company.

\section{Communication with Stakeholders as a Company CompetitivenessiFactor}

Research conducted by Michal Medek $(2006,69)$ as part of his doctoral thesis aimed to 'point out the influence of internal, external and crisis 
TA B LE 2 The Degree of Stakeholder Significance for a Company's Market Success

\begin{tabular}{lrrllrrr}
\hline Stakeholders & $\mathrm{M}$ & $\mathrm{SD}$ & & Stakeholders & $\mathrm{M}$ & $\mathrm{SD}$ \\
\cline { 1 - 2 } Customers & 9.7 & 0.9 & & Academic centres & 5.8 & 3.4 \\
Employees & 9.1 & 1.2 & & Local authorities & 5.4 & 2.8 \\
Management & 8.8 & 1.6 & & Government authorities & 5.3 & 3.0 \\
Owners & 8.3 & 2.4 & Consultancies & 4.8 & 3.1 \\
Suppliers & 7.9 & 2.1 & Citizens & 4.7 & 2.3 \\
Financial institutions & 5.9 & 3.0 & & Chamber of Commerce & 4.5 & 2.4 \\
Rivals & 5.8 & 2.3 & & Innovation centres & 3.0 & - \\
\hline
\end{tabular}

NOTES Adapted from Šimberová $(2008,17)$.

communications on company stability in the long term perspective, including their interdependence.' To meet this goal, he established a subobjective consisting in 'defining interest groups that are affected by corporate activities or that affect these activities through their behaviour, and dividing them into groups according to their effects and significance' (Medek 2006, 69).

Medek (2006) approached 178 enterprises, the response rate of the questionnaires accounted for $23 \%$. Results of the investigation were analysed separately through categories depending on company size (table 3 ).

Certain trends in the relation between company size and the significance of certain groups can be traced for the following groups:

- A growth in significance with a growth in company size: employees, authorities and public institutions, labour unions, schools and universities, financial analysts.

- A decline in significance with growth in company size: suppliers, shareholders, investors, rivals, employees' family members, consumer unions.

For the underlined groups the trend is more distinctive; the groups are ranked according to the overall significance of communication with them. Although the significance for communication should not be confused with the importance of these groups for company performance, it can suggest some implications.

\section{Relationships of Small and Medium-Sized Companies with Stakeholders in the South Moravian Region}

Kašparová and Klapalová examined 'motivations and expectations of the management of micro and small companies in relation to building and 
TAB LE 3 Significance of Communication with Different Stakeholder Groups for Companies

\begin{tabular}{lrrrrr}
\hline Stakeholder group & \multicolumn{5}{c}{ Number of employees* } \\
\cline { 2 - 6 } & $\leq 100$ & $101-$ & $501-$ & $\geq 1001$ & Total \\
& $(2)$ & 500 & 1000 & $(16)$ & \\
\hline Customers & $1-3$ & 1 & $1-3$ & 2 & 1 \\
Employees & $4-7$ & 2 & $1-3$ & 1 & 2 \\
Suppliers & $1-3$ & 3 & $1-3$ & $5-6$ & 3 \\
Shareholders & $1-3$ & 4 & 4 & 7 & 4 \\
Trade press & $4-7$ & 6 & $6-7$ & $5-6$ & 5 \\
Authorities and public institutions & $8-10$ & 7 & $6-7$ & 4 & 6 \\
Other media & $8-10$ & 5 & 5 & 10 & 7 \\
Investors & $4-7$ & 8 & 11 & 9 & 8 \\
Labour unions & $16-17$ & 11 & 8 & 3 & 9 \\
Schools and universities & $11-15$ & 9 & $8-10$ & 8 & 10 \\
Rivals & $4-7$ & 10 & $8-10$ & 14 & 11 \\
Former employees & $8-10$ & 15 & 14 & 11 & 12 \\
Financial analysts & $16-17$ & 14 & 15 & 12 & 13 \\
Political groups & $11-15$ & 17 & 12 & 15 & 14 \\
Interest associations from the vicinity & $11-15$ & 16 & 17 & 13 & 15 \\
Employees' family members & $11-15$ & 13 & 16 & 16 & 16 \\
Consumer unions & $11-15$ & 12 & 13 & 17 & 17 \\
\hline
\end{tabular}

NOTES ${ }^{*}$ Number of companies in the brackets. Adapted from Medek (2006, 85-93).

maintaining relationships with company stakeholders' on a sample of 20 small and medium-sized companies (Kašparová and Klapalová 2007, 717). It was part of an international research conclusion and the data presented are only a partial evaluation. For our purposes, the most interesting part is the evaluation of the significance of the individual stakeholders (or their groups), as well as the perceived benefits of these relationships. Respondents generally included members of the top management of the companies surveyed.

Table 4 shows the significance of the individual stakeholder groups; table 5 should provide the reasons for this significance - Kašparová and Klapalová asked the question 'Where do you see the benefits of these relationships.' 
TABLE 4 Mean Evaluations of the Significance of Each Stakeholder on a Scale of 1 to 10

\begin{tabular}{lrrlr}
\hline Stakeholder & $\mathrm{M}$ & & Stakeholder & $\mathrm{M}$ \\
\cline { 1 - 2 } \cline { 5 - 5 } Company management & 9.86 & & Local authorities & 4.46 \\
Customers & 9.65 & & Financial institutions & 4.00 \\
Employees & 8.90 & & Consultancies & 4.00 \\
Owners & 7.86 & Universities & 4.00 \\
Rivals & 6.43 & Government authorities & 3.72 \\
Suppliers & 6.35 & & Chamber of Commerce & 3.25 \\
Citizens & 4.80 & & \\
\hline
\end{tabular}

nOTES Adapted from Kašparová and Klapalová (2007, 723).

TABLE 5 Potential Benefits of Relationships with Different Stakeholder Types

\begin{tabular}{|c|c|}
\hline Stakeholders & Benefits \\
\hline Customers & $\begin{array}{l}\text { Customer loyalty (16), getting new customers (5), securing sta- } \\
\text { bility and creditworthiness (4), risk minimization (4), a must to } \\
\text { maintain business (4), building reputation and gaining prestige } \\
\text { (4), easier communication (3). }\end{array}$ \\
\hline Suppliers & $\begin{array}{l}\text { Getting non-financial benefits ( } 13) \text {, better conditions - cost- } \\
\text { cutting ( } 6 \text { ), securing stability ( } 5) \text {, a must to maintain business ( } 4 \text { ), } \\
\text { risk minimization ( } 3 \text { ). }\end{array}$ \\
\hline Employees & $\begin{array}{l}\text { Staff motivation and loyalty (12), getting non-financial benefits } \\
(7) \text {, cost-cutting (6). }\end{array}$ \\
\hline $\begin{array}{l}\text { Financial } \\
\text { institutions }\end{array}$ & $\begin{array}{l}\text { A must to maintain business ( } 7 \text { ), getting non-financial benefits } \\
(6) \text {, cost-cutting (3). }\end{array}$ \\
\hline $\begin{array}{l}\text { Government } \\
\text { authorities }\end{array}$ & A must to maintain business (9), problem-free business ( 7 ). \\
\hline Local authorities & $\begin{array}{l}\text { Getting non-financial benefits ( } 4 \text { ), loyalty of authorities as com- } \\
\text { pany clients (3), a must to maintain business (3). }\end{array}$ \\
\hline Consultancies & Getting non-financial benefits ( 3 ). \\
\hline $\begin{array}{l}\text { Other companies, } \\
\text { rivals }\end{array}$ & Getting new customers (6). \\
\hline Universities & Getting quality workforce (3). \\
\hline
\end{tabular}

NOTES Adapted from Kašparová and Klapalová $(2007,725)$. Response rates in the brackets include only reasons with a frequency at least 3 .

Kašparová and Klapalová (2007) concluded their report by stating that the surveyed companies build relationships especially with their primary stakeholders. The companies find the benefits of long-term relationships primarily in the non-financial benefits, such as trust in a partner. 


\section{The Significance of the Individual Groups in Relation to Performance} in the Czech Republic

Blažek and Částek (2009) tested the following hypothesis: 'the higher the significance of a particular stakeholder group is, the higher is financial performance of the company. Within the empirical survey of the Centre for the Competitiveness of the Czech Economy, they took advantage of a selected sample of 432 companies, which accounted for $15.33 \%$ of the population.

The questionnaire asked a question about identifying the significance of a relevant stakeholder group for the company on a scale from 1 (an unimportant stakeholder) to 5 (a very important stakeholder).

The relationship between the perceived significance of the interest groups and the achieved financial results was confirmed, but in general, the individual isolated relationships were weak. In many cases, these relationships were affected by moderating variables. For example, the significance of owners in the processing industry was found to be negatively associated to the corporate financial performance (Goodman-Kruskal's Gamma $=-0.2$ at $\alpha=0.005$ ), whereas in the construction industry it was found positive (although not statistically significant: $G=+0.2$ at $\alpha$ $=0.18$ ). This is consistent with the findings of Berman et al. (1999) that the dependency between stakeholder management and corporate performance cannot be examined at the level of a relationship to individual stakeholder groups.

\section{Conclusion}

The current level of development of the stakeholder theory makes it possible to apply it as a justification for the very existence of a company as well as a determinant of its performance, the latter being the object of our interest. For this paper, we set a goal to review empirical research of the relationship between stakeholder management and performance of companies. Empirical verification of such a relationship is not trivial, though. In the first place, the concept of stakeholder approach had to be defined and operationalized. For a review study such as this one, operationalization of the key concepts is important as it enables us to evaluate the reviewed studies. Thus, the first part of our study dealt with the operationalization of the stakeholder approach. The other important variable, i.e. business performance, was not addressed in such a detail; although one could argue that a partial overlap of the stakeholder theory into the 
field of business ethics opens the space to a discussion over the use of financial indicators as an appropriate measure, the reality of empirical studies is exceptionally unanimous here.

After taking these necessary steps, the actual review of the empirical studies starts with an examination of the static and dynamic effects of relationships to stakeholders on business performance, proceeds with two other studies to present the appropriate methodology, and after a brief justification of differentiating between 'Czech' and foreign studies begins the survey of 'Czech studies'.

The result of our review is rather unflattering. In general, several authors, regardless of whether they applied financial or non-financial measures of performance, empirically confirmed the positive relationship between the application of the stakeholder approach and company performance. The significance of positive relationships with stakeholders seems to be more critical for performance recovery than for its actual maintaining. However, the studies conducted on the companies based in the Czech Republic do not bring the same result. In fact, they do not bring any conclusive result. None of them researched the relationship in question in a sufficiently sophisticated way. Most of the studies assumed the existence of a positive relationship between the stakeholder approach and performance of Czech companies without any verification. If this topic was examined at all, it was done only at the level of isolated relationships towards the individual stakeholder groups. Moreover, the level of the relationship towards these groups was not measured adequately. For example, the significance or satisfaction of a stakeholder group should be measured using a set of multiple factors, as is apparent e.g. from the work by Harrison and Wicks (2013). However, no study of Czech companies proceeds in this way. It is therefore obvious that there is still a lot of work that needs to be done in this field.

In accordance with these facts and the studies and research presented above, it is possible to consider the application of stakeholder management justified in terms of performance. The growth in the level of expertise in this area, however, opens the space for answering new and more challenging questions that conform to the perspective of stakeholders in the context of their involvement in company performance that is diverse and conditioned with the complexity of real-world business conditions.

\section{References}

Barney, J. B. 2011. Gaining and Sustaining Competitive Advantage. Upper Saddle River, NJ: Pearson. 
Berman, S. L., A. C. Wicks, S. Kotha, and T. M. Jones. 1999. 'Does Stakeholder Orientation Matter? The Relationship between Stakeholder Management Models and Firm Financial Performance.' The Academy of Management Journal 42 (5): 488-506.

Blažek, L., and O. Částek. 2009. 'Stakeholder Approach and the Corporate Financial Performance.' Review of Economic Perspectives 9 (2): 90-106.

Bohata, M. 1998. 'Teorie Zajmovych Skupin: Moznosti a Limity'. Politicka Ekonomie 46 (5): 733-40.

Částek, O. 2010. 'Návrh Využití Stakeholderského Přístupu Při Strategické Analýze Podniku.' Doctoral thesis, Masaryk University, Brno.

Choi, J., and H. Wang. 2009. 'Stakeholder Relations and the Persistence of Corporate Financial Performance.' Strategic Management Journal 30 (8): 895-907.

de Bussy, N. M. 2010. 'Dialogue as a Basis for Stakeholder Engagement: Defining and Measuring the Core Competencies.' In The Sage Handbook of Public Relations, 127-44. 2nd ed. Thousands Oaks, c A: Sage.

de Bussy, N. M., and L. Suprawan. 2012. 'Most Valuable Stakeholders: The Impact of Employee Orientation on Corporate Financial Performance.' Public Relations Review 38 (2): 280-7.

Dohnalová, Z. 2007. 'Management of Relationships Between Company and Stakeholders.' Paper presented at the 7 th International Conference Enterprise in Transition, Split, 24-26 May.

Dohnalová, Z., and B. Zimola. 2014. 'Corporate Stakeholder Management.' Procedia: Social and Behavioral Sciences 110: 879-86.

Freeman, R. E. 1984. Strategic Management: A Stakeholder Approach. 1984. Boston, mA: Harper Collins.

Harrison, J. S., D. A. Bosse, and R. A. Phillips. 2010. 'Managing for Stakeholders, Stakeholder Utility Functions, and Competitive Advantage.' Strategic Management Journal 31 (1): 58-74.

Harrison, J. S., and A. C. Wicks. 2013. 'Stakeholder Theory, Value, and Firm Performance.' Business Ethics Quarterly 23 (1): 97-124.

Jones, T. M., A. C. Wicks, and R. E. Freeman. 2002. 'Stakeholder Theory? The State of the Art.' The Blackwell Guide to Business Ethics, edited by N. E. Bowie, 19-37. Malden, M A: Blackwell.

Kašparová, K., and A. Klapalová. 2007. 'Vztahy s me Se Stakeholdery v Jihomoravském Kraji.' In Vývojové tendence podniků 3: specifický výzkum katedry podnikového hospodářství, edited by L. Blažek, 717-30. Brno: Masarykova Univerzita.

Malý, M., M. Theodor, and J. Peklo. 2002. Řizení a správa společností. Praha: Vysoká škola ekonomická.

Medek, M. 2006. 'Komunikace se skupinami stakeholders jako faktor konkurenceschopnosti podniku.' Doctoral dissertation, Univerzita Tomáše Bati ve Zlíně, Zlín. 
Mitchell, R. K., B. R. Agle, and D. J. Wood. 1997. 'Toward a Theory of Stakeholder Identification and Salience.' The Academy of Management Review 22 (4): 853-86.

Orlitzky, M., F. Schmidt, and S. Rynes. 2003. 'Corporate Social and Financial Performance: A Meta-Analysis.' Organization Studies 24 (3): 40341.

Petrovicova, J., and K. Kasparova. 2009. 'The Relationships of the Slovak and Czech Enterprises towards Their Stakeholders (by Semantic Selection Test).' Ekonomie a Management 12 (2): 97-107.

Post, J. E., L. E. Preston, and S. Sachs. 2002a. 'Managing the Extended Enterprise: The New Stakeholder View. California Management Review 45 (1): 6-28.

- 2002b. Redefining the Corporation? Stakeholder Management and Organizational Wealth. Stanford, cA: Stanford Business Books.

Preston, L. E., and T. Donaldson. 1999. 'Stakeholder Management and Organizational Wealth.' The Academy of Management Review 24 (4): 61920.

Rais, S., and R. V. Goedegebuure. 2009. 'Stakeholder Orientation and Financial Performance: Evidence from Indonesia.' Problems and Perspectives in Management 7 (3): 62-75.

Robinson, G., and K. Dechant. 1997. 'Building a Business Case for Diversity.' The Academy of Management Executive 11 (3): 21-31.

Roman, R. M., S. Hayibor, and B. R. Agle. 1999. 'The Relationship between Social and Financial Performance: Repainting a Portrait.' Business and Society 38 (1): 109-25.

Šimberová, I. 2008. Řizení vztahů se stakeholdry na průmyslových trzích $v$ kontextu současných marketingových koncepcí: zkrácená verze habilitační práce. Vědecké spisy Vysokého učení technického v Brně: abilitační a inaugurační spisy 251. Brno: vUTIUM.

Šimberová, I., and D. Pollard. 2008. 'Stakeholder Relations Focus in Marketing Concepts of Companies.' Economics and Management, no. 13: 305-12.

Slabá, M., P. Starchon, and I. Jác. 2014. 'Identification and Prioritization of Key Stakeholder Groups in Marketing Communication of Colleges.' E+M Ekonomie a Management, no. 4: 101-10.

Šmakalova, P. 2012. 'Generic Stakeholder Strategy'. Economics and Management 17 (2): 659-63.

Theodor, M. 2004. 'A Stakeholder Approach to Measuring the Level of Corporate Governance.' Acta Oeconomica Pragensia, no. 5: 30-7.

Turban, D. B., and D. W. Greening. 1997. 'Corporate Social Performance and Organizational Attractiveness to Prospective Employees.' The Academy of Management Journal 40 (3): 658-72. 
Turnbull, S. 1997. 'Stakeholder Governance: A Cybernetic and Property Rights Analysis.' Corporate Governance 5 (1): 11-23.

Waddock, S. A., and S. B. Graves. 1997. 'The Corporate Social PerformanceFinancial Performance Link.' Strategic Management Journal 18 (4):30319.

This paper is published under the terms of the Attribution-

NonCommercial-NoDerivatives 4.o International (CC B Y-NC-ND 4.o)

License (http://creativecommons.org/licenses/by-nc-nd/4.o/). 